\title{
RISK FACTORS OF DIARRHEA AMONG COMMUNITIES LIVING NEARBY DELI RIVER AREA, NORTH SUMATERA
}

\author{
Elvita Susanti \\ Masters Program in Public Health, Universitas Sumatera Utara, Medan
}

\begin{abstract}
Background: Diarrheal disease is the second leading cause of death in children under five years old, and is responsible for killing around 525000 children every year. Interventions to prevent diarrhea, including safe drinking-water, use of improved sanitation and hand washing with soap can reduce disease risk. This study aimed to investigate risk factors of diarrhea among communities living nearby Deli river area, North Sumatera.

Subjects and Method : This was a cross-sectional study conducted in communities living nearby Deli river area, North Sumatera. A total of 96 subjects were selected for this study. The dependent variable was diarrhea incidence. The independent variables were use of toilet, clean water, hand wash, processing of waste, human excreta. The data were collected by questionnaire and analyzed by a multiple logistic regression.

Results : The risk of diarrhea increased with poor use of toilet $(\mathrm{PR}=1.67 ; 95 \% \mathrm{CI}$ 0.99 to $2.79 ; \mathrm{p}=0.040)$, poor use of clean water $(\mathrm{PR}=1.66 ; 95 \% \mathrm{CI} 1.02-2.70 ; \mathrm{p}=$ o.035), hand washing without soap ( $\mathrm{PR}=1.74 ; 95 \% \mathrm{CI} 1.12$ to $2.68 ; \mathrm{p}=0.002)$, poor garbage management $(\mathrm{PR}=2.5 \mathrm{O} ; 95 \% \mathrm{CI} 1.33$ to $4.89 ; \mathrm{p}=0.001)$, improper human excreta disposal ( $\mathrm{PR}=1.64 ; 95 \% \mathrm{CI} 1.04$ to $2.60 ; \mathrm{p}=0.032)$.

Conclusion: The risk of diarrhea increases with poor use of toilet, poor use of clean water, hand washing without soap, poor garbage management, and improper human excreta disposal.
\end{abstract}

Keywords: diarrhea, personal hygiene, sanitation.

\section{Correspondence:}

Elvita Susanti. Masters Program in Public Health, Universitas Sumatera Utara, Jl. Universitas No. 21, Medan, North Sumatera. Email:elvitasusantiskm@gmail.com. Mobile: 081375520310, o8116005324. 